\section{US 119, An Intergeneric Hybrid Citrus Scion Breeding Line}

\author{
H.C. Barrett \\ U. S. Department of Agriculture, Agricultural Research Service, 2120 \\ Camden Road, Orlando, FL 32803
}

Additional index words. Citrus sinensis, Poncirus trifoliata, fruit breeding, cold resistance, tristeza virus resistance

Florida has experienced at least 11 severe freezes in the past 150 years, including some of the most destructive freezes recorded, that have seriously affected world citrus production. One-fourth of Florida's 52 million citrus trees were lost in the 1962 freeze, with an estimated total tree and fruit loss of $\$ 500$ million. The series of three freezes in the 5year period of 1981 through 1985 destroyed 130,000 ha out of the 340,000 ha total in 1980. Severe freezes have had a serious economic impact on the more than $\$ 1$ billion on-the-tree crop value per year of the Florida citrus industry. Freeze injury is probably the most important factor limiting citrus production in Florida (Yelenosky, 1978).

Citrus tristeza virus (CTV) is the most economically important virus pathogen of citrus and it is one of the major citrus disease problems worldwide. Millions of trees on sour orange rootstock have been killed or rendered unproductive by a CTV-induced decline in Argentina, Brazil, the United States, Spain, and Venezuela. A serious stem-pitting disease of susceptible scion cultivars is caused by some isolates of CTV even when propagated on tolerant rootstocks (Garnsey and Lee, 1988). The development of CTV-

Received for publication 9 Apr. 1990. The cost of publishing this paper was defrayed in part by the payment of page charges. Under postal regulations, this paper therefore must be hereby marked advertisement solely to indicate this fact. resistant or immune scion cultivars would eliminate the bud-union-type reaction of the decline syndrome on CTV-intolerant rootstocks and the stem-pitting syndrome of susceptible scion cultivars on CTV-tolerant rootstocks (Garnsey et al., 1987).

The certainty of recurring severe freezes in Florida, the worldwide experience with the destruction of citrus trees caused by CTV, and the spread of more virulent strains of CTV in Florida led to the initiation of a U.S. Dept. of Agriculture (USDA), Agricultural Research Service, Breeding Program in 1973 to find genetic solutions to these problems. The objective of this breeding program was to develop citrus scion breeding lines combining resistance to freezing and CTV, satisfactory edibility, and, ultimately, to develop commercially useful cultivars combining these and other desirable traits. The citrus scion breeding line described herein is the first release from this breeding program (Barrett, 1981).

\section{Origin}

US 119 originated from a 1973 cross of T9R80, an $F_{1}$ intergeneric hybrid selection [Citrus paradisi Macfayden cv. Duncan $\mathrm{x}$ Poncirus trifoliata (L.) Rafinesque], by Cit- 
rus sinemis (L.) Osbeck cv. Succory. The hybrid seedlings grown from this seed were planted at the A.H. Whitmore Foundation Farm of the USDA near Leesburg, Fla., and US 119 was selected from a progeny of 173 plants in 1980. The original genetic source for resistance to freezing and CIV that was used to develop this scion breeding line was an unnamed selection of $P$. trifoliata, an inedible relative of Citrus.

\section{Description}

The tree of US 119 is moderately vigorous, with dense, dark-green foliage of predominantly unifoliate leaves with a variable component of bi- and trifoliate leaves among them. The foliage is very resistant to freeze injury and has remained alive and green after the foliage of most citrus cultivars has been killed by cold. The average fruit is $\approx 70 \mathrm{~mm}$ in diameter, weighs $165 \mathrm{~g}$, and has a $3-\mathrm{mm}$ thick rind that is slightly pebbly due to numerous oil glands. Fruit shape is globose and resembles a medium-sized sweet orange in external and internal color, appearance, and morphology (Fig. 1); it also has the unusual combination of fine-textured and very firm flesh. At maturity in late November, the fruit has produced juice samples with soluble solids concentrations ranging from $12.0 \%$ to $17.2 \%$ and titratable acidity from $0.63 \%$ to $0.81 \%$. The flavor is sweet and similar to sweet orange, but it does not equal sweet orange in overall quality factors. Seeds are few, about five to six per fruit, medium size, and $95 \%$ to $100 \%$ nucellar. Cracking of fruit has occurred in some years, especially when the weather at time of maturity was alternately wet and dry. US 119 survived the series of severe freezes of 1981, 1983, and 1985 , with an estimated low of $-12.2 \mathrm{C}$ in 1981. Although largely defoliated in the 1981 freeze, this selection has bloomed and produced fruit each year since its original selection in 1980. In a more rigorous freezeresistance test at Byron, Ga., small 1-yearold trees were frozen back to ground level after an estimated $-19.4 \mathrm{C}$ low (unpublished data). This selection consistently has given negative enzyme-linked immunosorbent assay readings when inoculated with five strains of CTV of Florida origin (Garnsey et al., 1981, 1987) and, more recently, to five severe-strain CTV isolates from California, Brazil, Japan, South Africa, and Spain made under quarantine (S.M. Garnsey, personal communication). High CTV resistance (negative readings) is transmitted to some individual seedlings in hybrid progenies derived from crosses between US 119 and both nonCTV-infectible (negative) and CTV-infectible (positive) clones (unpublished data).

\section{Availability}

A limited supply of virus-free budwood is available by written request to Farm Superintendent, A.H. Whitmore Foundation Farm, Route 2, Box 375, Groveland, FL 32736.

\section{Literature Cited}

Barrett, H.C. 1981. Breeding cold-hardy citrus scion cultivars. Proc. Intl. Soc. Citriculture 1:6166.

Garnsey, S.M., H.C. Barrett, and D.J. Hutchison. 1981. Resistance to citrus tristeza virus in citrus hybrids as determined by enzyme-linked immunosorbent assay. Phytopathology 71:875. Garnsey, S.M., H.C. Barrett, and D.J. Hutchison. 1987. Identification of citrus tristeza virus resistance in citrus relatives and its potential ap- plications. Phytophylactica 19: 187-191.

Garnsey, S.M. and R.F. Lee. 1988. Tristeza, p. 48-50. In: J.O. Whiteside, S.M. Garnsey, and L.W. Timmer (eds.). Compendium of citrus diseases. APS Press, St. Paul, Minn.

Yelenosky, G. 1978. Freeze survival of citrus trees in Florida, p. 197-312. In: P.H. Li and H. Sakai (eds.). Plant cold hardiness and freezing stress. Academic, New York. 